\section{Compost in the 20th Century: A Tool to Control Plant Diseases in Nursery and Vegetable Crops}

\author{
Gladis M. Zinati ${ }^{1}$
}

ADDITIONAL INDEX WORDs. biocontrol agents, biological control, mechanisms of disease suppression, methyl bromide alternative, Phytophthora, pythium root rot, Rhizoctonia solani, Trichoderma

Summary. The discovery of disease suppression in certain bark composts increased the interest in using compost as growing substrate to control root rot diseases caused by Phytophthora cinnamomi. Disease suppression mechanisms include antibiosis, competition, hyperparasitism, and induced systemic resistance. Although abiotic factors may influence disease suppression, the latter is often based on microbial interactions - the two common mechanisms being general for pythium (Pythium spp.) and phytophthora root rot (Phytophthora spp.) and specific for rhizoctonia (Rbizoctonia solani). The discovery of disease suppression agents in compost led to the development of biocontrol agent-fortified compost during the last decade of the 20th century. The suggested recommendations for future research and extension outreach may include 1) development of methods to manage bacterial and viral diseases through the use of compost; 2) exploration of the potential effects of fortified compost on insect pests suppression; 3 ) improvement of inoculation methods of composts with biocontrol agents to produce consistent levels of disease suppression at the commercial scale; 4) development of effective fortified compost teas for suppressing foliar diseases; 5) education of compost producers on methods of production of fortified compost that suppress specific diseases; and 6) education of end-users on uses of fortified compost and its by-products.

\footnotetext{
${ }^{1}$ Assistant Professor and Nursery Management Specialist, Rutgers University, Department of Plant Biology and Pathology, 166 Foran Hall, 59 Dudley Road, New Brunswick, NJ 08901. E-mail: zinati@aesop. rutgers.edu

Acknowledgments. The author would like to express her appreciation to Ms. Rewa Choueiri and Dr. Kimberly Klock Moore for editing this manuscript.
}

Historical review

$\mathrm{F}$ or many years, organic amendments, including animal and green manures, coupled with crop rotation were the principal methods of fertilization and soilborne disease control (Baker and Cook, 1974). These management practices were replaced with usage of high quantities of lowcost synthetic nitrogenous fertilizers and soil-sterilizing pesticides (e.g., methyl bromide) in the early part of the 20th century (De Ceuster and Hoitink, 1999). The latter approaches rendered soils more prone to diseases due to recolonization with plant pathogens within days of soil treatment (Bollen, 1974). Plant pathogen recolonization may have significant negative impacts on crop yields in the absence of biocontrol agents (De Ceuster and Hoitink, 1999). Losses due to soilborne diseases on some greenhouse, nursery, and vegetable crops can amount to thousands of dollars per acre annually.

In the 1960s the nursery industry encountered increasingly serious problems with root rot disease caused by Phytophthora cinnamomi due to the reintroduction of pathogen via infected plants, after soil fumigation, or in irrigation water (Hoitink, 1980). The first report on suppression of a soilborne disease by application of tree bark was from Oregon State University (Houck, 1962). Observations made in nurseries indicated that phytophthora root rot of rhododendron (Rhododendron spp.) was less severe on plants produced in media amended with tree bark compost than in those amended with peat (Hoitink, 1980). In addition, the search for low-cost substitutes for peat in substrate media led the nursery industry to explore the possibility of using wood waste composts (Hoitink et al., 1991).

During the 1970s and 1980s improved procedures in aging and composting tree bark led to increased compost utilization, and revealed the side benefits of reducing losses caused by phytophthora root rot (Gugino et al., 1973; Hoitink and Fahy, 1986; Hoitink et al., 1977).

Hoitink(1980) reported that root rots did not occur in media with 4 bark: 1 peat ratios. The use of tree bark compost reduced the incidence of soilborne diseases not only in nursery crops but also in floriculture and foliage crops. Similarly, Spring et al. (1980) showed that losses of 3-week-old apple (Malus pumila) seedlings, due to Phytophthora cactorum, were significantly lower in bark-compost-container medium than in peat medium after inoculation.

In the 1990s the effects of suppressing soilborne pathogens by amending soils with composted sewage sludge were noted by Lumsden et al. (1983) for rhizoctonia root rot (Rhizoctonia solani) on beans (Phaseolus vulgaris), cotton (Gossypium spp.), and radish (Raphanus sativus); sclerotinia drop (Sclerotinia sclerotiorum) of lettuce (Lactuca sativa); fusarium wilt (Fusarium oxysporum f.sp. cucumerinum) of cucumber (Cucumis satious); and phytophthora crown rot (Phytophthora capsici) of pepper (Capsicum annuиm). These diseases were all significantly decreased by amending soil with compost. Hadar and Mandelbaum (1986) showed that licorice root compost suppressed the damping off caused by Pythium aphanidermatum in cucumber. Throughout the 1980 s, various studies showed that composted organic residues suppressed Phytophthora cinnamomi, Rhizoctonia solani, and Fusarium oxysporum in many crops (Hoitink, 1980; Hoitink and Fahy, 1986; Nelson and Hoitink, 1982; Spring et al., 1980).

Some studies have shown that composted bark may induce suppression effects after steam sterilization and others may not. For example, Broadbent et al. (1971) reported that beneficial bacteria such as Bacillus and Streptomyces species, which are antagonistic to fungal root pathogens, have been shown to survive steam treatment of $60.0^{\circ} \mathrm{C}\left(140^{\circ} \mathrm{F}\right)$ for 30 min, whereas studies by Hardy and Sivasithampram (1991) have shown that potting medium amended with composted eucalyptus (Eucalyptus cinere) bark (CEB) became conducive to root rot after steam sterilization. It appeared that the suppression effect of CEB was in decreasing order to Phytophthora cryptogea, P. nicotianae var. nicotianae, $P$. citricola, $P$. drechsleri, and P. cinnamomi infections of the nursery plants waratah (Telopea speciosissima) and banksia (Banksia occidentalis). Throughout the 1990s, nursery industry has, in some cases successfully, replaced methyl bromide fumigation with disease suppressive compost and reduced the uses of fungicides (Quarles and Grossman, 1995). 


\section{Mechanisms of biological control in composts}

Most compost products suppress pythium and phytophthora root rot naturally, while only some suppress rhizoctonia and very few induce systemic resistance in plants (Zhang et al., 1996). Abiotic factors (e.g., high $\mathrm{pH}$ and nature of the clays (montmorillonite) have been shown to be involved in soilborne disease suppression (Amir and Alabouvette, 1993; Hoper et al., 1995), based on two mechanisms: general and specific microbial interactions. General disease suppression (Cook and Baker, 1983), which is based on microbial competition for energy, involves the total soil microflora (Serra-Wittling et al., 1996). Propagules of plant pathogens such as Pythium and Phytophthora species are suppressed through the general suppression phenomenon (Boehm et al., 1993; Chen et al., 1988a, 1988b; Cook and Baker 1983; Hardy and Sivasithamparam, 1991; Mandelbaum and Hadar, 1990). Specific disease suppression refers to a specific group of microorganisms antagonizing the pathogen. Such group may include non-pathogenic Fusarium species (Larkin et al., 1993; Serra-Wittling et al., 1996) and fluorescent pseudomonas (Pseudomonas fluorescens) (Scher and Baker, 1982; Larkin et al., 1993). The biological control for Rhizoctonia solani, by a narrow group of antagonistic microorganisms, is described as specific suppression.

Edaphic microorganisms stimulated by compost amendments contribute to the suppressive activity of the amended soils through four control mechanisms: antibiosis, competition, predation hyperparasitism, and the induction of systemic acquired resistance in the host plant (Lockwood, 1988).

Antibiosis is the inhibition of one organism's growth by a metabolic product (such as antibiotic) being produced by another organism (Baker and Cook, 1974). Many organisms, especially soil fungi and actinomycetes, produce antibiotic substances. Three diseases have been found to be controlled by antibiosis: armillaria root rot (Armillaria mellea) by Trichoderma viride, pythium and rhizoctonia damping off and stem and root rot disease by Pseudomonasfluorescens, and crown gall (Agrobacterium tumefaciens) by
Agrobacterium radiobacter. The most widely accepted commercial example is the use of strain 84 to control of crown gall, one of the most serious diseases of stone fruit trees in nurseries and of many other woody plants. Agrobacterium radiobacter and particularly one strain, strain 84, produces large quantities of a bacteriocin, now called agrocin.

Competition is when organisms compete for nutrients (particularly high-energy carbohydrates, nitrogen and iron) (Duijff et al., 1994; Raaijmakers et al., 1995), infection sites, and possibly certain environmental factors such as oxygen and space (Baker and Cook, 1974).

Parasitic and predatory fungi are known to parasitize plant pathogens resulting in lysis or death. Such organisms may include Rhizoctonia solani on species of Pythium (Butler, 1957), Trichoderma viride on Armillaria mellea (Duddington and Wyborn, 1972) and Tuberculina maxima and Fusarium roseum on rust (Cronartium ribicola) (Kimmey, 1969). Verticillium dabliae is reported to parasitize even itself (Griffiths and Campbell, 1970). Microorganisms including Trichoderma such as $T$. hamatum and $T$. harzianum are considered the predominant fungal parasites recovered from composts prepared from lignocellulosic wastes (Kuter et al., 1983; Nelson et al., 1983) and capable of eradicating Rhizoctonia solani (Hoitink et al., 1991). When suitable antagonists are already present in the soil or substrate but do not provide a satisfactory level of disease control, it may be desirable to intensify their activity. This may be accomplished by one or more of the following methods: 1) crop rotation; 2) adding amendments to stimulate antagonists; 3 ) altering soil $\mathrm{pH}$ to favor the antagonist, inhibit the pathogen, or both; 4) employing tillage methods that modify soil structure and aeration; 5 ) selection of a planting date to reduce disease incidence; 6) applying organic amendments in such a way as to reduce the available nitrogen at the infection side; and 7) managing irrigation practices to maintain soil water potential favorable to antagonists at infection sites (moist for bacteria, drier for actinomycetes), and still ensure water available for the plant.

Mechanisms of induced systemic resistance include activating the pro- duction of salicylic acid; defense related proteins and or other compounds in plants that eventually lead to a systemic resistance to pathogens such as anthracnose (Colletotrichum orbiculare) in cucumber (Hoitink et al., 1997a). Other studies have shown that peroxidase activity, an enzyme associated with protection mechanisms against stress, was higher in leaves of cucumber plants grown in biologically fortified compost than in the leaves of those grown in a peat mix. In addition, the activity of an enzyme, a "pathogenesis-related (PR) protein," was increased more rapidly in plants grown in compost than plants grown in peat or sterilized compost after being inoculated with the pathogen (Hoitink et al., 1997a).

\section{Disease suppression as affected by microbial composition}

In practice, composts are not consistently or naturally colonized by a broad spectrum of biocontrol agents because the latter are destroyed by high temperatures during active composting. To be effective biocontrol agents must recolonize composts during the curing process and this does not always occur. For example, composts produced near a forest are much more likely to become colonized by effective biocontrol agents and more consistent in suppressing rhizoctonia diseases than those produced in an enclosed system (Kuter et al., 1983). Effective control of Rhizoctonia solani can be achieved by applying isolates of Trichoderma species combined with any of several bacterial biocontrol agents.

Copiotrophic bacteria recolonize composts most rapidly (24-48 h) after peak heating of compost (Chen et al., 1988a; Kwok et al., 1987). The predominant biocontrol agents in this group include strains of Bacillus, Pseudomonas, and Pantoea species (Boehm et al., 1997; Kwok et al., 1987). Oligotrophic bacteria do not reach peak populations until 18-24 $\mathrm{d}$ into the curing phase (Chen et al., 1988a). Obligate oligotrophs isolated from composts are suppressive to pythium root rot and appear ineffective at inducing biological control of pythium damping-off when applied as seed treatments. In contrast to obligate oligotrophs, facultative oligotrophic strains (as those belong to the genus Pseudomonas) are highly effective bio- 
logical control agents when applied as seed treatments. Actinomycetes also contribute significantly to biological control provided by composts (Hardy and Sivasithampram, 1995; You and Sivasithampram, 1995).

\section{Compost quality and biological control}

Compost must be stable and of consistent quality to be used successfully for biological control of diseases in horticultural crops (Inbar et al., 1993). Biological control rarely eliminates a pathogen, but rather reduces its numbers or its ability to produce disease. Such control may be achieved with little or no reduction in the pathogen population (Baker and Cook, 1974).

Consistent and sustained biological control of diseases can be achieved in different compost-amended growing media as long as variables such as consistency of the parent organic material, moisture content, salinity, carbon to nitrogen ratio and process parameters are controlled in the compost (Hoitink et al., 1991).

Parent material of Feedstock. Fungal composition seems to be influenced by the chemistry of the parent organic material from which the compost is prepared. Composts prepared from lignocellulosic substances such as tree barks become colonized predominantly by Trichoderma species (Kuter et al., 1983) which in turn these beneficial fungi control Rhizoctonia solani (Grebus et al., 1994; Kwok et al., 1987; Nelson et al., 1983). In contrast, grape pomace, which is low in cellulosic substances and high in sugars, becomes colonized by Penicillium and Aspergillus species (Gorodecki and Hadar, 1990) and consequently these parasitic fungi eradicate sclerotia of Sclerotium rolfsii (Hadar and Gorodecki, 1991).

Compost maturity. Variability in suppression of rhizoctonia damping-off and fusarium wilt encountered in substrates amended with mature composts is due, in part, to random recolonization of compost by effective biocontrol agents after peak heating (Hoitink et al., 1997b). Rhizoctonia solaniis a highly competitive saprophyte. It can utilize cellulose and colonize fresh bark but cannot colonize mature bark compost because of low cellulose content. However, isolates of Trichoderma species grow as a saprophyte in fresh compost and function via hy- perparasitism as biocontrol agents for Rhizoctonia solani in mature compost (Chung and Hoitink, 1990; Hoitink and Fahy, 1986).

Moisture CONTENT AND PH. The moisture content of compost affects the ability of bacterial mesophiles to colonize the substrate after peak heating. Compost with $<34 \%$ moisture $\mathrm{w} / \mathrm{w}$ could be colonized by fungi and are conducive to pythium diseases (Hoitink et al., 1997b). Disease suppression could be induced by increasing moisture content to at least 40\%-50\% $\mathrm{w} / \mathrm{w}$, for beneficial bacteria and fungi to colonize the substrate after peak heating, whereas a $\mathrm{pH}<5.0$ inhibits growth of bacterial biocontrol agents (Hoitink et al., 1991).

IRRIGATION, TEMPERATURE, AND RATE OF APPLICATION. Irrigation practices, temperature and of rate of application of compost can affect losses to diseases. For example, substrate mixes with composted pine bark are used to suppress fusarium wilt. However, such mixes with $45 \%$ compost $(\mathrm{v} / \mathrm{v})$ have low capillary activity and cannot be used in an ebb-and-flow irrigation system to suppress wilt.

In 1988, a mix formulation made of composed of pine bark $(25 \% \mathrm{v} / \mathrm{v})$, light sphagnum and perlite effectively suppressed Fusarium oxysporum f. sp. cyclaminis disease and performed well in ebb and flow system in the U.S. (Hoitink et al., 1991).

Salts. Composts prepared from manures contain considerable amounts of sodium and chloride (De Ceuster and Hoitink, 1999). It has been shown in field trials that high salinity products must be applied in the fall or winter well ahead of planting to allow for leaching and thus avoid an increase in phytophthora root rot of certain crops (Hoitink and Schmitthenner, 1988). The nursery industry uses up to $80 \%$ of pine bark in potting mixes, bark composts tend to be lower in salinity than sludge or manure composts, and up to $15 \%(\mathrm{v} / \mathrm{v})$ of compost derived from manure or sludge (Hoitink et al., 1991).

Nitrogen, AND CARBON:NITrogen (C:N) RATio. Phytophthora dieback of rhododendron (caused by P. nicotianae) (Hoitink et al., 1986), fusarium wilt of cyclamen (Hoitink et al., 1987) and fireblight (Erwinia amylovora) are examples of diseases that are increased in severity as a result of excessive $\mathrm{N}$ fertility introduced into container media with composted biosolids. Schneider (1985) speculated that the low $\mathrm{C}: \mathrm{N}$ in predominantly high ammonium and low nitrate-nitrogenreleasing sludge compost enhanced fusarium wilts. Compost with high $\mathrm{C}$ : $\mathrm{N}$ materials, such as tree barks, immobilizes ammonium-N and suppresses fusarium diseases if colonized by an appropriate microflora (Trillas-Gay et al., 1986).

LEVEL OF ORGANIC MATTER DECOMPOSITION AND MICROBIAL ACTIVITY. Decomposition of organic matter can affect the composition of bacterial taxa as well as the populations and activities of biocontrol agents. Green manures, stable manures and composts can provide food for biological control agents if applied well ahead of planting (Lumsden et al., 1983), and can be very effective in controlling diseases such as Pythium, Phytophthora, Fusarium, and Rhizoctonia solani.

Decomposition level of organic matter in potting mixes or soils is overlooked by many specialists working with biocontrol agents. Fresh (undecomposed) organic matter does not support colonization by biocontrol agents. High concentrations of available nutrients (glucose, amino acids, etc.) in fresh crop residues repress the production of enzymes required for parasitism by biocontrol agents such as Trichoderma species (De Ceuster and Hoitink, 1999). Flavobacterium balustinum 299 and Trichoderma hamatum 382 have been identified in compost to induce systemic resistance in plants. Both microflora and organic matter in sphagnum peat can affect suppression of soilborne diseases. Organic matter in sphagnum peat generally does not support high microbial activity because peat resists decomposition. Dark decomposed peat is low in activity and is consistently conducive to pythium root rot, whereas light peat is less decomposed and has higher microbial activity (De Ceuster and Hoitink, 1999). Peat can be used effectively, if colonized by biocontrol agents, for short production cycles such as in plug and flat mixes used in bedding plant industry. This is because the effect of biocontrol agents in peat is of short duration to suppress pythium root rots. Hence, the "slow release" nature of the organic nutrients in mature composts and in light peat supports activity of microflora and thus sustains biocontrol. 


\section{Prediction of disease suppression based upon organic matter decomposition}

Effectiveness of disease suppression can be estimated by determining organic matter decomposition status in compost. Recalcitrant materials (lignins and lignin-protected cellulose) that are resistant to decomposition, sustain the activities of biocontrol agents (Hoitink et al., 2000). After these recalcitrant materials are decomposed, the beneficial microorganisms decline in activity, the pathogen population recovers and increases; and fungicides must be applied for sensitive crops to remain disease free (Boehm et al.,1997; Hoitink et al., 2000). The compost users can test organic matter content and compost maturity before compost is used to estimate likely disease suppression. Nondestructive direct spectroscopic procedures, utilizing nuclear resonance spectroscopy (NMR) and Fourier transform infrared (FT-IR), are now being used to determine the amount of undecomposed biodegradable organic matter remaining in compost (Chen and Inbar, 1993; Inbar et al., 1989).

\section{Prediction of disease suppression based on microbial activity}

Effectiveness of disease suppression can be estimated by measuring microbial activity in compost. This can be achieved by an enzyme assay based on the rate of hydrolysis of fluorescein diacetate (FDA) by lipases, esterases and proteases (Schnurer and Rosswall, 1982). The hydrolysis rate of FDA by microorganisms is believed to be related to suppression of root rots caused by Pythium and Phytophthora species (Boehm and Hoitink, 1992). High microbial biomass and FDA activity in readily biodegradable materials (such as composted sewage-sludges and manures) induce suppression in potting mixes at low $(10-15 \% \mathrm{v} / \mathrm{v})$ amendment rates (Boehm and Hoitink, 1992; Chen et al., 1988b; Mandelbaum and Hadar 1990; You and Sivasithamparam, 1994). In contrast, composts containing more recalcitrant lignins, such as pine bark and hardwood bark, must be incorporated at higher rates $(50 \%)$. The duration of FDA activity in such composts is defined as the length of time that suppression effects last relative to biological control. It is also referred to as "carrying capacity" (Boehm et al., 1993).

\section{Production of consistent fortified compost}

To produce and maintain compost quality in relation to both plant growth and disease control, producers of composts must understand the processes involved in this method of biological control. Biocontrol agentfortified compost seems to have the greatest opportunities for utilization and commercialization as components of commercially manufactured potting media. Composted pine bark fortified with Flavobacterium balustinum 299 and T. hamatum 382 has been very effective in controlling fusarium wilt of cyclamen, rhizoctonia diseases, as well as phytophthora and pythium root rots of other greenhouse container crops (Krause et al., 1997). Drenching potting mixes with soil fungicides may cost $\$ 10 /$ yard $^{3}\left(\$ 13.08 / \mathrm{m}^{3}\right)$ per application of mix (De Ceuster and Hoitink, 1999). Some crops need to be treated more than once, such as Easter lily (Lilium longiflorum), azalea (Rhododendron macrosepalum), poinsettia (Euphorbia pulcherrima) and rhododendron. However, biocontrol agents can be inoculated into compost-amended mixes for less than $50 \%$ of the cost of a single combination fungicide drench (De Ceuster and Hoitink, 1999).

Although treatments with single biocontrol agents have had little effect, combinations of several Trichoderma species and bacterial biocontrol agents have proved effective in mixes amended with bark compost (Hoitink, et al., 1991). Consistent disease suppression of both rhizoctonia and pythium damping off was not found among compost batches in full scale production plants. This suggests that the mechanisms of suppression of these diseases in commercial composted pine bark mixes differ. Therefore, the addition of biocontrol agents could be beneficial to obtaining and maintaining "quality" by inducing consistent levels of suppression of damping-off by species of Rhizoctonia, assuming successful inoculations.

Compost made from spruce and hemlock bark and inoculated with Trichoderma hamatum 382 and Flavobacterium balustinum 299 was formulated into a potting mix containing compost, peat and perlite (Grebus et al., 1993). The fortified compost consistently suppressed pythium root rot of cucumber as well as rhizoctonia damping off and fusarium wilt of radish. The mix continued to be suppressive even after 4 months of storage.

\section{Future opportunities}

More research and extension outreach on production and usage of compost and compost byproducts are needed. In the future, research should focus on managing bacterial diseases and perhaps reducing the severity of some virus diseases by utilizing fortified composts to induce systemic resistance. In addition, more research is needed on the effects of compost on the suppression of insect pests and the mechanisms that might control such suppression. Although the rate of hydrolysis of FDA can be used effectively to estimate potential suppression of potting mix to pythium root rot, more practical procedures to quantify suppression based on microbial activity and organic matter decomposition need to be developed. Improvement in inoculation methods of compost with biocontrol agents, to produce consistent levels of disease suppression at the commercial scale, is needed. Furthermore, development of effective compost extracts and teas for enhancing plant growth and foliar disease suppression is needed.

Extension education and outreach should focus on educating compost producers to choose correct feedstocks for making compost with biological agents to suppress disease. Similarly, education should be extended to compost end-users such on choosing compost that enhances crop yields and suppresses diseases.

\section{Literature cited}

Amir, H. and C. Alabouette. 1993. Involvement of soil abiotic factors in the mechanisms of soil suppressiveness to fusarium wilts. Soil Biol. Biochem. 25:157-164.

Baker, K. F. and R.J. Cook. 1974. Biological control of plant pathogens. Freeman, San Francisco.

Boehm, M.J. and H.A.J. Hoitink. 1992. Sustenance of microbial activity and severity of pythium root rot of poinsettia. Phytopathology 82:259-264. 
Boehm, M.J., L.V. Madden, and H.A.J. Hoitink. 1993. Effect of organic matter decomposition level on bacterial species diversity and composition in relationship to pythium damping-off severity. Appl. Environ. Microbiol. 59:4171-4179.

Boehm, M.J., T. Wu, A.G. Stone, B. Krakman, D.A. Iannotti, G.E. Wilson, L.V. Madden, and H.A.J. Hoitink, 1997. Cross-polarized magic-angle spinning $13 \mathrm{C}$ nuclear magnetic resonance spectroscopic characterization of soil organic matter relative to culturable bacterial species composition and sustained biological control for pythium root rot. Appl. Environ. Microbiol. 63(1):162-168.

Bollen, G.J. 1974. Fungal recolonization of heat-treated glasshouse soils. AgroEcosystems 1:139-155.

Broadbent, P., K.F. Baker, and Y. Waterworth. 1971. Bacteria and actinomycetes antagonistic to fungal root pathogens in Australian soils. Austral. J. Biolog. Sci. 24:925-944.

Butler, E.E. 1957. Rhizoctonia solani as a parasite of fungi. Mycologia 49:354373.

Chen, W., H.A.J. Hoitink, and L.V. Madden. 1988a. Microbial activity and biomass in container media predicting suppressiveness to damping-off caused by Pythium ultimum. Phytopathology 78:1147-1450.

Chen, W., H.A.J. Hoitink, A.F. Schmitthenner, and O.H. Tuovinen. 1988b. The role of microbial activity in suppression of damping-off caused by Pythium ultimum. Phytopathology 78:314-322.

Chen, Y. and Y. Inbar. 1993. Chemical and spectroscopical analyses of organic matter transformations during composting in relation to compost maturity, p. 551-600. In: H.A.J. Hoitink and H.M. Keener (eds.). Science and engineering of composting: Design, environmental, microbiological and utilization aspects. Renaissance Publ., Worthington, Ohio.

Chung, Y.R. and H.A.J. Hoitink. 1990. Interactions between thermophilic fungi and Trichoderma bamatum in suppression of rhizoctonia damping-off in a bark compost-amended container medium. Phytopathology 80:73-77.

Cook, R.J. and K.F. Baker. 1983. The nature and practice of biological control of plant pathogens. Amer. Phytopathol. Soc. Press, St. Paul, Minn.

De Ceuster, T.J. and H.A.J. Hoitink. 1999. Prospects for composts and biocontrol agents as substitutes for methyl bromide in biological control of plant diseases. Compost Sci. Utilization 7:6-10.
Duddington, C.L. and C.H.E. Wyborn. 1972. Recent research on the nematophagous Hyphomycetes. Bot. Rev. 38:545-565.

Duijff, B.J., P.A.H.M. Bakker, and B. Schippers. 1994. Suppression of fusarium wilt of carnation by Pseudomonasputida WCS358 at different levels of disease incidence and iron availability. Biocontrol Sci. Technol. 4:279-288.

Gorodecki, B. and Y. Hadar. 1990. Suppression of Rhizoctonia solani and Sclerotium rolfsii in container media containing composted separated cattle manure and composted grape marc. Crop Protection 9:271-274.

Grebus, M.E., K.A. Feldman, C.A. Musselman, and H.A.J. Hoitink. 1993. Production of biocontrol agent-fortified compost-amended potting mixes for predictable disease suppression. Phytopathology 83:1406.

Grebus, M.E., M.E. Watson, and H.A.J. Hoitink. 1994. Biological, chemical and physical properties of composted yard trimmings as indicators of maturity and plant disease suppression. Compost Sci. Utilization 2:57-71.

Griffiths, D.A. and W. Campbell. 1970. Interaction between hyphae of Verticillium dabliae during microsclerotial development. Can. J. Microbiol. 16:1132-1133.

Gugino, J.L., F.A. Pokorny, and F.F. Hendrix, Jr. 1973. Population dynamics of Pythium irregulare in container-plant production as influenced by physical structure of media. Plant Soil 39:591-602.

Hadar, Y. and B. Gorodecki. 1991. Suppression of germination of sclerotia of Sclerotium rolfsii in compost. Soil Biol. Biochem. 23:303-306.

Hadar, Y. and R. Mandelbaum 1986. Suppression of Pythium aphanidermatum damping-off in container media containing composted liquorice roots. Crop Protection 5:88-92.

Hardy, G.E. and K. Sivasithampram.1991. Suppression of phytophthora root rot by a composted eucalyptus bark mix. Austral. J. Bot. 39:153-159.

Hardy, G.E. and K. Sivasithampram.1995. Antagonism of fungi and actinomycetes isolated from composted eucalyptus bark to Phytophthora drechsleri in a steamed and non-steamed composted medium. Soil Biol. Biochem. 27:243-246.

Hoitink, H.A.J. 1980. Composted bark, a lightweight growth medium with fungicidal properties. Plant Dis. 64(2):142-147.

Hoitink, H.A.J., M. Daughtery, and H.K. Tayama. 1987. Control of cyclamen fu- sarium wilt-A preliminary report. Ohio Florist's Assn. Bul., 693:1-3.

Hoitink, H.A.J., D.M. van Doran, and A.F. Schmitthenner. 1977. Suppression of Phytophthora cinnamomi in a composted hardwood bark potting medium. Phytopathology 67:561-565.

Hoitink, H.A.J. and P.C. Fahy. 1986. Basis for the control of soilborne plant pathogens with compost. Annu. Rev. Phytopathol. 24:93-114.

Hoitink, H.A.J., M.S. Krause, and A.G. Stone. 2000. Disease control induced by composts in container culture and ground beds. Orn. Plants Annu. Rpt. Res. Rev. 2000. 18 June 2004. <http://ohioline. osu.edu/sc177/sc177_15.html>.

Hoitink, H.A.J., Y. Inbar, and M.J. Boehm. 1991. Status of compost-amended potting mixes naturally suppressive to soilborne diseases in floricultural crops. Plant Dis. 75:869-873.

Hoitink, H.A.J. and A.F. Schmitthenner. 1988. Effects of composted municipal sludge on soilborne plant pathogens. 15 May 2003. <http://www.epa.gov/epaoswer/non-hw/compost/disease.pdf>.

Hoitink, H.A.J., W. Zhang, D. Han, and W. Dick. 1997a. Making compost to suppress plant disease. BioCycle 38: 40-42.

Hoitink, H.A.J., A. G. Stone, and D.Y. Han. 1997b. Suppression of plant diseases by composts. HortScience 32:184-187.

Hoitink, H.A.J., M.E. Watson and W.R. Faber. 1986. Effect of nitrogen concentration of juvenile foliage of rhododendron on phytophthora dieback severity. Plant Dis. 70:292-294.

Hoper, H., C. Steinberg, and C. Alabouvette. 1995. Involvement of clay type and $\mathrm{pH}$ in the mechanism of soil suppressiveness to fusarium wilt of flax. Soil Biol. Biochem. 27:955-967.

Houck, L. 1962. Factors influencing development and control of Phytophthora fragariae, the cause of red stele disease of strawberries. PhD Diss., Oregon State Univ., Corvallis.

Inbar, Y., Y. Chen, and Y. Hadar. 1989. Solid-state carbon-13 nuclear magnetic resonance and infrared spectroscopy of composted organic matter. Soil Sci. Soc. Amer. J. 53:1695-1701.

Inbar, Y., Y. Hadar, and Y. Chen. 1993. Recycling of cattle manure: The composting process and characterization of maturity. J. Environ. Qual. 22:857-863.

Kimmey, J.W. 1969. Inactivation of lethaltype blister rust cankers on western white pine. J. For. 67:296-299. 
Krause, M.S., C.A. Musselman, and H.A.J. Hoitink. 1997. Impact of sphagnum peat decomposition level on biological control of rhizoctonia damping-off of radish induced by Flavobacterium balustinum 299 and Trichoderma hamatum 382. Phytopathology 87:S55.

Kuter, G.A., E.B. Nelson, H.A.J. Hoitink, and L.V. Madden. 1983. Fungal populations in container media amended with composted hardwood bark suppressive and conductive to rhizoctonia damping-off. Phytopathology 73:1450-1456.

Kwok, O.C.H., P.C. Fahy, H.A.J. Hoitink, and G.A. Kuter. 1987. Interactions between bacteria and Trichoderma hamatum in suppression of rhizoctonia damping-off in bark compost media. Phytopathology 77:1206-1212.

Larkin, R.P., D.L. Hopkins, and F.N. Martin. 1993. Ecology of Fusarium oxysporumf. sp. niveum in soils suppressive and conducive to fusarium wilt of watermelon. Phytopathology 83:1105-1116.

Lockwood, J.L. 1988. Evolution of concepts associated with soilborne plant pathogens. Annu. Rev. Phytopathology 26:93-121.

Lumsden, R.D., J.A. Lewis, and P.D. Miller. 1983. Effect of composted sewage sludge on several soilborne pathogens and diseases. Phytopathology 73:1543-1548.

Mandelbaum, R. and Y. Hadar 1990. Effects of available carbon source on microbial activity and suppression of $P y$ thium aphanidermatum in compost and peat container media. Phytopathology 80:794-804.
Nelson, E.B. and H.A.J. Hoitink. 1982. Factors affecting suppression of Rhizoctonia solaniin container media. Phytopathology 72:275-279.

Nelson, E.B., G.A. Kuter, and H.A.J. Hoitink. 1983. Effects of fungal antagonists and compost age on suppression of rhizoctonia damping-offin container media amended with composted hardwood bark. Phytopathology 73:1457-1462.

Quarles, W. and J. Grossman. 1995. Alternatives to methyl bromide in nurseries-Disease suppressive media. IPM Practitioner 17:1-13.

Raaijmakers, J.M., M. Leeman, M.M.P. Van Oorschot, I. Van der Sluis, B. Schippers, and P.A.H.M. Bakker. 1995. Doseresponse relationships in biological control of fusarium wilt of radish by Psendomonas spp. Phytopathology 85:1075-1081.

Scher, F.M. and R. Baker. 1982. Effects of Pseudomonasputida and synthetic iron chelator on induction of soil suppressiveness to fusarium wilt pathogens. Phytopathology 72:1567-1573.

Schneider, R.W. 1985. Suppression of fusarium yellow of celery with potassium chloride and nitrate. Phytopathology $75: 40-48$.

Schnurer, J. and T. Rosswall. 1982. Fluorescein diacetate hydrolysis as a measure of total microbial activity in soil and litter. Appl. Environ. Microbiol. 43:1256-1261.
Serra-Wittling, C., S. Houot, and C. Alabouvette. 1996. Increased soil suppressiveness to fusarium wilt of flax after addition of municipal solid waste compost. Soil Biol. Biochem. 8:1207-1214.

Spring, D.E., M.A. Ellis, R.A. Spotts, H.A.J. Hoitink, and A.F. Schmitthenner. 1980. Suppression of the apple collar rot pathogen in composted hardwood bark. Phytopathology 70:1209-1212.

Trillas-Gay, M.I., H.A.J. Hoitink, and L.V. Madden. 1986. Nature of suppression of Fusarium wilt of radish in container medium amended with composted hardwood bark. Plant Dis. 70:1023-1027.

You, M.P. and K. Sivasithampram. 1994. Hydrolysis of fluorescein diacetate in an avocado plantation mulch suppressive to Phytophthora cinnamomi and its relationship with certain biotic and abiotic factors. Soil Biol. Biochem. 26:1355-1361.

You, M.P. and K. Sivasithampram. 1995. Changes in microbial populations in an avocado plantation mulch suppressive to Phytophthora cinnamomi. Appl. Soil Ecol. $2: 33-43$.

Zhang, W., W.A. Dick, and H.A.J. Hoitink. 1996. Compost-induced systemic acquired resistance in cucumber to phythium root rot and anthracnose. Phytopathology 86:1066-1070. 